[Agr. Biol. Chem., Vol. 29, No. 4, p. 307 314, 1965]

\title{
Studies on Proteolytic Enzyme of the Cricket, Gryllulus taiwanemma Ohmachi
}

\author{
By Tadayoshi Nakashima*, Kiyochika Tokuyasu ${ }^{* *}$ and Masaru Funatsu \\ Laboratory of Biochemistry, Faculty of Agriculture, Kyushu University, Fukuoka
}

Received October 12, 1964

\begin{abstract}
A protease was isolated from the alimentary canal of crickets. This cricket protease was purified by ammonium sulfate, rivanol and acetone fractionations, and DEAE-cellulose and $\mathrm{CM}$-cellulose (Ca-form) column chromatographies. The optimum temperature was $50^{\circ} \mathrm{C}$ and the optimum $\mathrm{pH}$ was 8.0. For preservation, the enzyme was most stable at $\mathrm{pH} 3.0$. Aluminum had the best stabilizing action with no drops of enzyme activity after 24 hours of dialysis. The cricket protease was specific for the synthetic substrate, $\alpha$-benzoyl-Larginine amide. Cricket protease had a $K_{m} .10^{3}$ of 2.8 which is similar to that of trypsin, 1.2. The Ea was 3,770 while that of trypsin was 14,960 using $\alpha$-benzoyl-L-arginine amide as the substrate. Although cricket protease has the same substrate specificity and similar optimum $\mathrm{pH}$ and $\mathrm{pH}$-stability as trypsin, it differed in metal requirements to obtain activity. Certain metals are essential for cricket protease activity.
\end{abstract}

\section{INTRODUCTION}

In insects such as the housefly, the American cockroach, and the blowfly, proteolytic enzymes have been demonstrated, but little progress has been made in isolating and purifying the enzymes. ${ }^{1,2)}$ These insect proteolytic enzymes, like trypsin, are active at neutral or alkaline $\mathrm{pH}$. Attempts have been made to compare insect proteases with mammalian trypsin but consistent results were not obtained. ${ }^{3)}$ The present study deals with the purification and characterization of cricket protease and some comparative investigations concerning mammalian trypsin and other insect protease. It was felt that knowledge of proteases of different species of life may be gained. Because the cricket is omnivorous

* Institute for Molecular Evolution, Univ. of Miami, Florida, U.S.A.

** Lab. of Biochem., Faculty of Pharm., Univ. of Nagasaki, Nagasaki, Japan.

1) S. Lin and A. G. Richards, Ann. Ent. Soc. Amer., 49, 239 (1956).

2) V.J. Brookes, Biochim. Biophys. Acta, 46, 13 (1961).

3) D. Gilmour, "Biochemistry of Insects" Academic Press. New York and London, 1961, p. 53.
}

and capable of agricultural crop (wheat) destruction, it was felt of interest to study the protease of this insect. The cricket, Gryllulus taiwanemma Ohmachi was selected as the experimental insect because of the comparative ease in isolating the alimentary canal from the adult. The adult body of the cricket is relatively free of fat, thus simplifying operational procedures to remove the alimentary tract.

\section{MATERIALS AND METHODS}

\section{Chemical Reagents}

Rivanol was purchased from the Daiichi Seiyaku Company (Japan). DEAE-cellulose and CM-cellulose were obtained from Brown Company (U.S.A.). $\alpha$ Benzoyl-L-arginine amide $\mathrm{HCl}, \mathrm{N}$-acetyl-L-tyrosine amide, N-carbobenzoxy-glycyl-L-phenylalanine, and L-leucine amide $\mathrm{HCl}$ were obtained from the Sigma Chemical Company (U.S.A.).

Cultivation of Crickets and Isolation of Alimentary Canal as Enzyme Source.

Cultivation of adult Cryllulus taiwanemma Ohmachi was done by the following method. Adults (male and female) were placed in a 10-liter glass jar con- 
taining a sand layer of the bottom. The open end was covered by a fine meshed screen. The female lay their eggs directly into the sand layer. After $2 \sim 3$ weeks of incubation at $28^{\circ} \mathrm{C}$ the appearance of larvae is noted. These larvae being omnivorous can be raised of food such as fresh cabbage, uncooked potatoes and soybeans, yeast, and dried sardine. The larvae grew into adults and began to reproduce in a period of three months. In all instances the temperature was maintained at $28^{\circ} \mathrm{C}$. The adult crickets were placed in a refrigerator at $4^{\circ} \mathrm{C}$ until they were immobile. A slit was then made in the ventral side of the abdomen and the cut exterior layer was penned to a cork surface. The anterior and posterior ends of the alimentary canal were cut off with a scissors and the canal was removed with a forceps. Digestive juices are found only in the midgut ${ }^{4}$ ) of these crickets. Because of difficuty to isolate the midgut only, the entire alimentary canal was employed as enzyme source in the experiments.

\section{Enzyme Assay}

Protease activity was determined by the method of Hagiwara, 51 which is a modification of the procedure by Kunitz, ${ }^{6}$ with the exception that it was carried out at $50^{\circ} \mathrm{C}$ rather than $30^{\circ} \mathrm{C}$. Activity was determined by the amount of casein hydrolyzed. A unit of enzyme was indicated by the designation PU. One PU was the amount of the enzyme that produced one microgram $(\mu \mathrm{g})$ of tyrosine from casein in one minute. Tyrosine was determined by measuring the absorbancy at $278 \mathrm{~m} \mu$ using a Beckman model DU spectrophotometer.

\section{Protein Determination}

Protein concentration was determined by the microKjeldahl method.

\section{Ninhydrin Procedure}

The method of Yemm and Cocking ${ }^{7 \cdot 8)}$ was employed in determining the amount of ammonia liberated from $\alpha$-benzoyl-L-arginine amide by protease.

\section{RESULTS}

\section{1) Purification of Cricket Protease.}

The following procedure was used for puri-

4) V.B. Wigglesworth, "Insect Physiology," Methuen Co. Ltd, London, 1956, p. 39.

5) B. Hagiwara, in Koso Kenkyuho ed. by S. Akabori,

Vol. 2, Asakura Shoten, Tokyo, 1962, p. 240.

6) M. J. Kunitz, Gen. Physiol, 30, 291 (1947).

7) E.W. Yemm and E. C. Cocking, Analyst, 80, 209 (1955).

8) E. W. Yemm and E.C. Cocking, Biochem. J., 58, xi (1954). fication of protease extracted from the alimentary canal of crickets. All steps were performed in the cold room at $5^{\circ} \mathrm{C}$.

Step 1. Homogenization of the alimentary tract: To 23 grams of isolated alimentary tract $230 \mathrm{ml}$. of cold distilled water was added and the preparation was homogenized in a PotterElvehjem homogenizer. The homogenized preparation was adjusted to $\mathrm{pH} 4.0$ with $10 \%$ acetic acid and allowed to stand overnight.

Step 2. Initial Extract: The homogenized preparation was centrifuged at $30,000 \times \mathrm{g}$ for 30 minutes. The supernatant was collected by decantation and the sediment was discarded.

Step 3. Ammonium Sulfate Fractionation: The supernatant from Step 2 was saturated with ammonium sulfate and allowed to stand overnight. The resulting precipitate was collected by centrifugation at $30,000 \times \mathrm{g}$ for 30 minutes and dissolved in tap water. The solution was placed in Visking tubings and dialyzed overnight against running tap water. Resulting insoluble material in the tubings was sedimented by centrifugation and discarded.

Step 4. Rivanol ${ }^{9 /}$ and Acetone Fractionations: To the supernatant, $0.2 \%$ rivanol in $1 / 2$ volume was added. The yellow precipitate formed was collected by centrifugation and discarded. To the supernatant acetone was added to $70 \%$ saturation. After standing 3 hours, the resulting light brown precipitate or crude protease was collected by centrifugation at $30,000 \times \mathrm{g}$ for 30 minutes. The supernatant was discarded.

Step 5. DEAE-cellulose Treatment: The light brown precipitate or crude protease was dissolved in $15 \mathrm{ml}$. of water and was passed through a DEAE-cellulose column $(0.7 \times 10 \mathrm{~cm})$ at a flow rate of $0.5 \mathrm{ml}$. per minute. The DEAE-cellulose column was washed with distilled water. In this step the crude protease solution became colorless and there was

9) S. Akabori, B. Hagiwara and T. Ikenaka, Froc. Japan Acad., 27, 350 (1951). 
a singnificant increase in specific activity of the column-passed protease solution.

Step 6. CM-cellulose Column Chromatography: One tenth of the volume of the protease solution which was passed through DEAE-cellulose was subjected to CM-cellulose chromatography. Since the CM-cellulose was relatively small the procedure was repeated as necessary. The enzyme solution was placed on a CM-cellulose column, $0.7 \times 10 \mathrm{~cm}$,

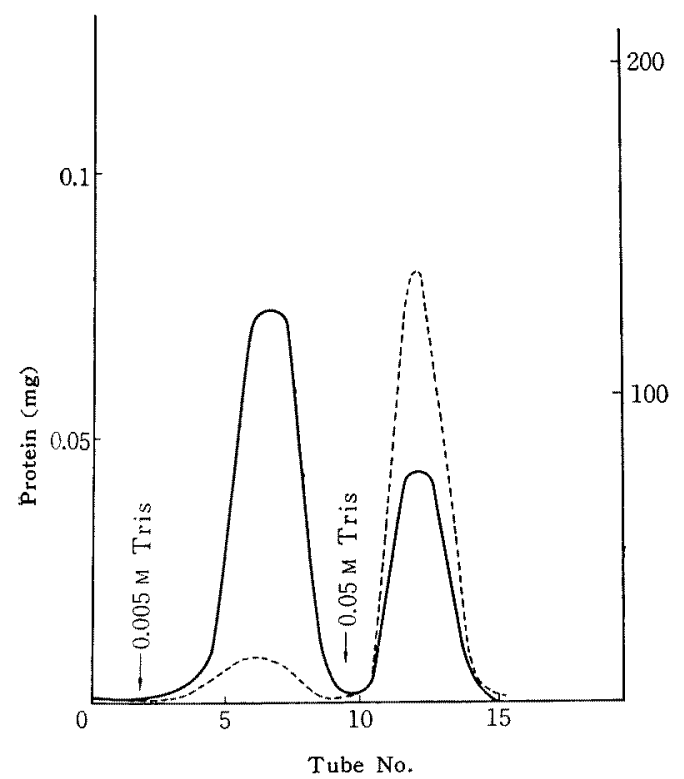

FIG. 1. CM-cellulose Chromatography of Purified Cricket Proteolytic Enzyme.

Fractions of $2 \mathrm{ml}$. were collected at a flow rate of $0.5 \mathrm{ml}$. per minute. Solid line represents protein concentration and the broken line activity. which had been equilibrated with $5 \times 10^{-3} \mathrm{M}$ Tris $\mathrm{HCl}$ buffer, $\mathrm{pH} 7.6$, containing $0.01 \mathrm{~m}$ $\mathrm{CaCl}_{2}$. The adsorbed material was first eluted with approximately $20 \mathrm{ml}$. of the equilibrating buffer, then with $20 \mathrm{ml}$. of $5 \times 10^{-2} \mathrm{M}$ Tris HCl buffer, $\mathrm{pH} 7.6$, containing $0.01 \mathrm{~m}$ $\mathrm{CaCl}_{2}$. The elution pattern is shown in Fig. 1 .

The initial peak is probably due to the material not adsorbed to the column. The protease activity was low in comparison to the nitrogen concentration suggesting the presence of a considerable amount of impurities. The second peak eluted with $5 \times 10^{-2} \mathrm{M}$ Tris $\mathrm{HCl}$ buffer, pH 7.6, containing $0.01 \mathrm{M} \mathrm{CaCl}_{2}$ had relatively high activity in comparison to its nitrogen concentration. It is apparent that the enzyme is in a relatively pure state. This enzyme fraction was used for subsequent studies.

The results of the purification procedure are summarized in Table I.

2) Properties of Enzyme

(A) Effect of temperature and $\mathrm{pH}$ on enzyme activity. The CM-cellulose-fractionated enzyme was subjected to various $\mathrm{pH}$ values and temperatures in order to determine the optimum $\mathrm{pH}$ and temperature with respect to activity. Casein was used as the substrate to determine enzyme activity. ${ }^{\text {") }}$

For optimum $\mathrm{pH}$ determination Clark and Lubs buffer was used for $\mathrm{pH} 2.0$ to 9.0 and Borax-sodium hydroxide buffer for $\mathrm{pH} 10.0$ and 11.0. A selected temperature of $50^{\circ} \mathrm{C}$ was used. Fig. 2 shows that the optimum $\mathrm{pH}$ was 8.0 .

Table I. Purification of Cricket Protease

\begin{tabular}{|c|c|c|c|c|c|c|}
\hline Step & $\begin{array}{l}\text { Volume } \\
\mathrm{ml}\end{array}$ & $\begin{array}{c}\text { Activity } \\
\text { PU }\end{array}$ & $\begin{array}{l}\text { Protein } \\
\text { mg }\end{array}$ & $\begin{array}{l}\text { Specific } \\
\text { activity } \\
\text { PU/mg }\end{array}$ & Purity & $\begin{array}{c}\text { Yield } \\
\%\end{array}$ \\
\hline 1. Homogenized suspension & $270^{*}$ & 57,800 & - & - & - & 100 \\
\hline 2. Initial extract & 230 & 32,200 & 183.0 & 176 & 1.0 & 56 \\
\hline 3. Ammonium sulfate fractionation & n 38 & 20,900 & 40.3 & 520 & 3.0 & 36 \\
\hline 4. Rivanol, acetone fractionation & 15 & 10,500 & 18.5 & 570 & 3.2 & 18 \\
\hline 5. DEAE-cellulose effluent & 32 & 9,280 & 5.0 & 1856 & 10.6 & 16 \\
\hline 6. CM-cellulose chromatography & 46 & 6,030 & 1.9 & 3180 & 18.1 & 10 \\
\hline
\end{tabular}


For optumum temperature determination phosphate buffer, $\mathrm{pH}$ 8.0, was used for all temperatures. Fig. 3. indicates $50^{\circ} \mathrm{C}$ is the optimum temperature.

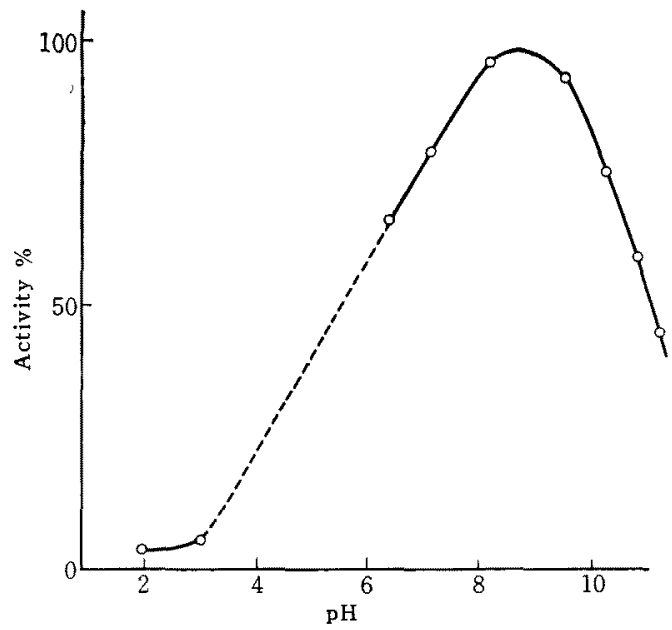

FIG. 2. Effect of $\mathrm{pH}$ on Enzyme Activity.

Activity was measured at $50^{\circ} \mathrm{C}$ using casein as substrate and expressed as relative activity assuming the activity at pH 8 to be 100 .

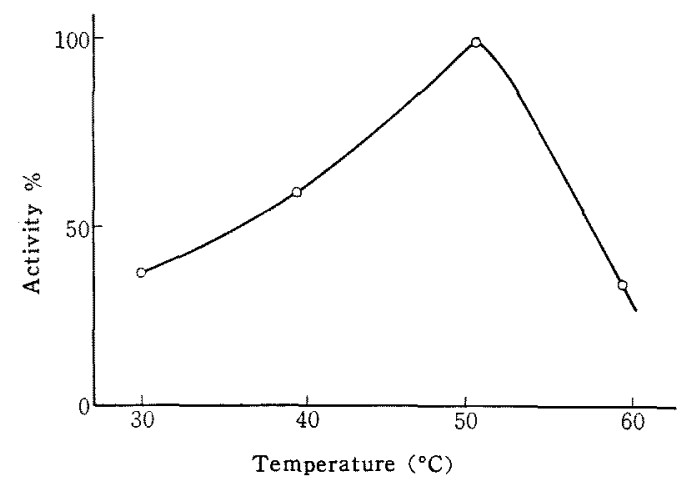

FIG. 3. Effect of Temperature on Enzyme Activity.

Activity was measured at $\mathrm{pH} 8.0$ using casein as substrate and expressed as relative value assuming the activity at $50^{\circ} \mathrm{C}$ to be 100 .

(B) Optimum pH and temperature of the purified protease using the substrate $\alpha$-benzoyl- $L$ arginine amide (BAA). Assay results were recorded as optical densities at a wavelength of $570 \mathrm{~m} \mu$. Fig. 4 shows an optimum of $\mathrm{pH}$ 8.3 for the enzyme and Fig. 5 indicates an

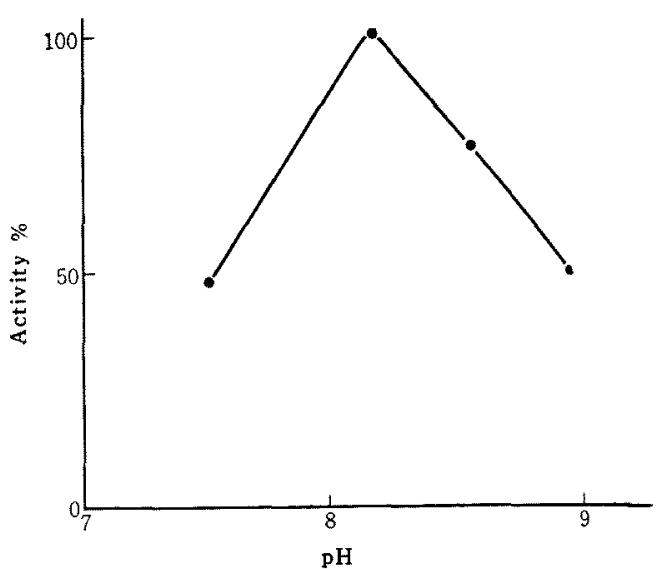

FIG. 4. Effect of $\mathrm{pH}$ on the Enzyme with BAA as Substrate.

Activity was determined at $50^{\circ} \mathrm{C}$ and expressed as relative activity assuming the activity obtained at $\mathrm{pH} 8.3$ to be 100 .

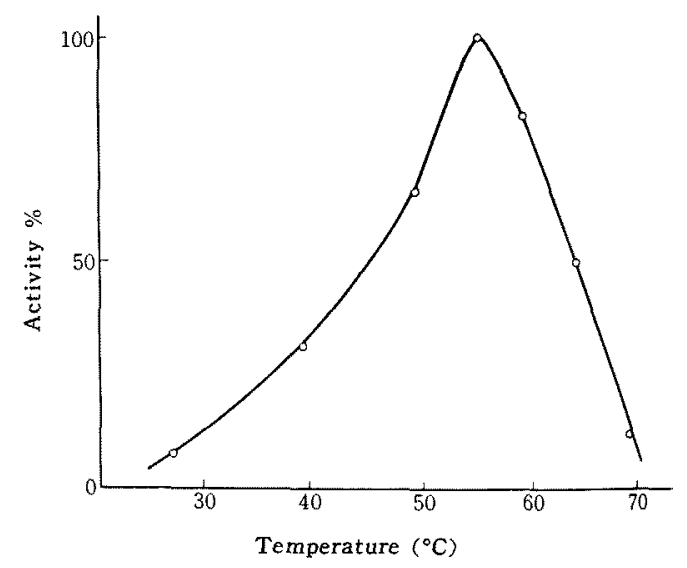

FIG. 5. Effect of Temperature on the Enzyme with BAA as Substrate.

Activity was determined at $\mathrm{pH} 8.3$ and expressed as relative activity assuming the activity obtained at $55^{\circ} \mathrm{C}$ to be 100 .

optimum temperature of $55^{\circ} \mathrm{C}$.

(C) $\mathbf{p H}$ Stability. Preservation of the purified protease preparation, CM- cellulose-fraction, was examined at 0 and $20^{\circ} \mathrm{C}$ for a period of 3 days at various $\mathrm{pH}$ values. To cover the desired $\mathrm{pH}$ range, Clark and Lubs ( $\mathrm{pH} 3.0 \sim 8.0$ ) and borax-sodium hydroxide (pH 9.0 11.0) buffers were employed. From Fig. 6 it is obvious for both temperatures 
that $\mathrm{pH} 3.0$ was most suitable for preserving enzyme activity. The rate of inactivation increased rapidly from $\mathrm{pH} 9.0$ to 11.0 .

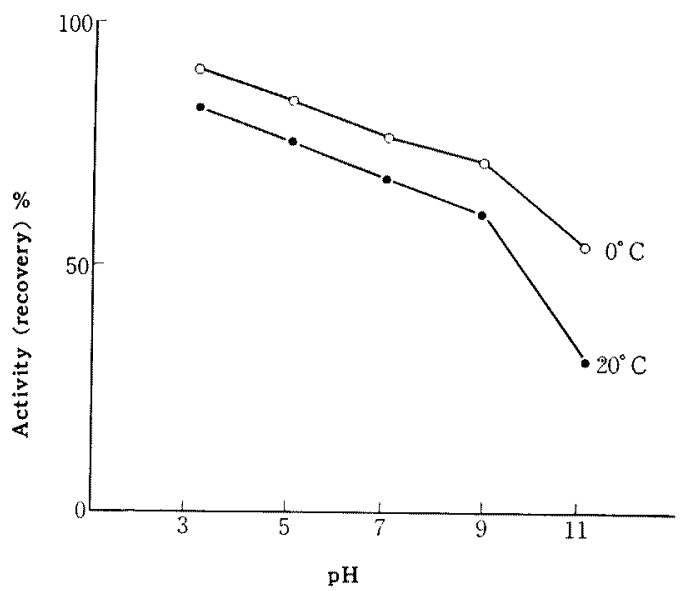

FIG. 6. Preservation of Protease at 0 and $20^{\circ} \mathrm{C}$ for 3 Days at Various $\mathrm{pH}$ Values.

Activity was determined at $50^{\circ} \mathrm{C}$ and $\mathrm{pH} 8.0$ after readjustment, using casein as substrate and expressed as percentage of recovery.

(D) Effect of salts on enzyme activity. Each of a half $\mathrm{ml}$. aliquots of the enzyme solution with an initial PU of 36 was placed in separate Visking tubings which were dialyzed against salt solutions of various concentrations. There were three changes of the salt solution during the $24 \mathrm{hrs}$. dialysis period. Dialysis was carried out at $5^{\circ} \mathrm{C}$. Table II shows the effect of various salts on enzyme activity. In distilled water alone, there was complete drop in activity but with the incorporation of metals in the water the decrease in activity was not so significant. This indicates that the metals act as enzyme stabilizers. There was no inactivation of the enzyme in the presence of $0.66 \times 10^{-2} \mathrm{M}$ aluminium chloride. Aluminium was the best stabilizer. Iron chloride $0.66 \times 10^{-2} \mathrm{M}$ was the poorest with no stabilizing action.

(E) Substrate specificity. Various synthetic substrates with known enzyme specifity were used in this study. $\alpha$-Benzoyl-L-arginine amide
TABLE II. EFFECT OF VARIOUS SALTS ON ENZYME ACTIVITY

$\begin{array}{crrc}\text { Salt } & \mathrm{pH} & \mathrm{PU} & \begin{array}{c}\text { Inactiva- } \\ \text { tion }(\%)\end{array} \\ \text { Dist. water } & 5.7 & 0 & 100 \\ 0.66 \times 10^{-4} \mathrm{M} \mathrm{AlCl}_{3} & 5.2 & 0 & 100 \\ 10^{-3} \mathrm{M} \mathrm{AlCl}_{3} & 4.5 & 34 & 5 \\ 10^{-2} \mathrm{M} \mathrm{AlCl}_{3} & 4.2 & 36 & 0 \\ 10^{-2} \mathrm{M} \mathrm{CrCl}_{3} & 3.6 & 20 & 45 \\ 10^{-2} \mathrm{M} \mathrm{FeCl}_{3} & 2.7 & 0 & 100 \\ 1 \times 10^{-2} \mathrm{M} \mathrm{CaCl}_{2} & 4.2 & 27 & 25 \\ \mathrm{MgCl}_{2} & 5.7 & 21 & 42 \\ \mathrm{ZnCl}_{2} & 5.9 & 19 & 47 \\ \mathrm{MnCl}^{2} & 5.7 & 20 & 45 \\ \mathrm{CoCl}_{2} & 5.7 & 18 & 50 \\ 2 \times 10^{-2} \mathrm{M} \mathrm{Kal} & 5.2 & 18 & 50 \\ \mathrm{NaCl} & 5.2 & 20 & 44 \\ \mathrm{NaNO}_{3} & 5.4 & 24 & 33 \\ \mathrm{Na}_{2} \mathrm{SO}_{4} & 5.4 & 27 & 25 \\ \left.\mathrm{Ca} \mathrm{CCH}_{3} \mathrm{COO}\right)_{2} & 6.7 & 28 & 22\end{array}$

specific for trypsin; acetyl-L-tyrosine amide specific for chymotrypsin; carbobenzoxyglycyl-L-phenylalanine specific for carboxypeptidase; and L-leucine amide specific for aminopeptidase were employed. These substrates were used in $0.2 \mathrm{~m}$ concentration in the presence of one $\mathrm{ml}$. of the enzyme $(0.1$ $\mathrm{mg} \mathrm{N} / \mathrm{ml}$.) at $\mathrm{pH} 8.3$ and $50^{\circ} \mathrm{C}$. The CMcellulose-purified proteolytic enzyme hydrolyed only $\alpha$-benzoyl-L-arginine amide, indicating its similarity to trypsin.

3) Kinetic Study of the Enzyme

(A) The effect of substrate concentration (S) on the rate of enzyme reaction $(v)$. The rate of enzyme reaction was plotted against substrate concentration at various temperatures ranging from 19.5 to $50^{\circ} \mathrm{C}$ using $\mathrm{BAA}$ as the substrate. The results obtained are shown in Fig. 7.

(B) Determination of the maximum velocity $\left(V_{\max }\right)$ and the Michaelis constant $\left(K_{m}\right)$ of the reaction. From the data obtained in Fig. 7. three methods of plotting were used to obtain the $V_{\max }$ and $K_{m}$. The Lineweaver-Burk plot, ${ }^{10)}$ the Hofstee plot ${ }^{11}$ and the Augustins-

10) H. Lineweaver and D. Burk, J. Amer. Chem. Soc, 56, 658 (1934).

11) B. H. Hofstee, Science, 116, 329 (1952). 


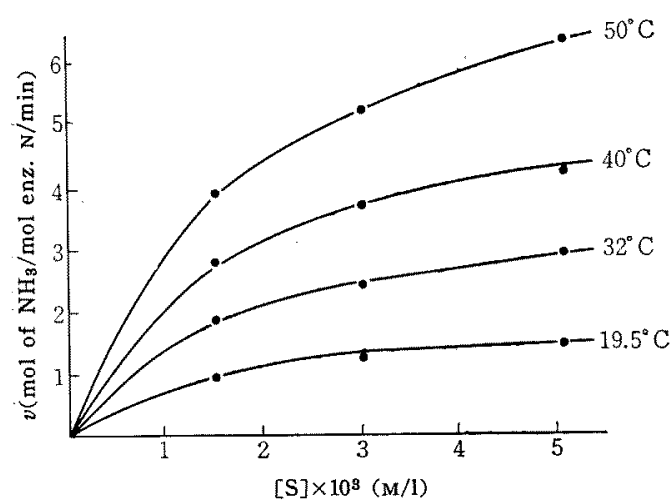

FIG. 7. Velocity-Substrate Concentration ( $v$-S) Curves at Various Temperatures.

The reaction rate was measured at $\mathrm{pH} 8.3$ using $\mathrm{BAA}$ as substrate.

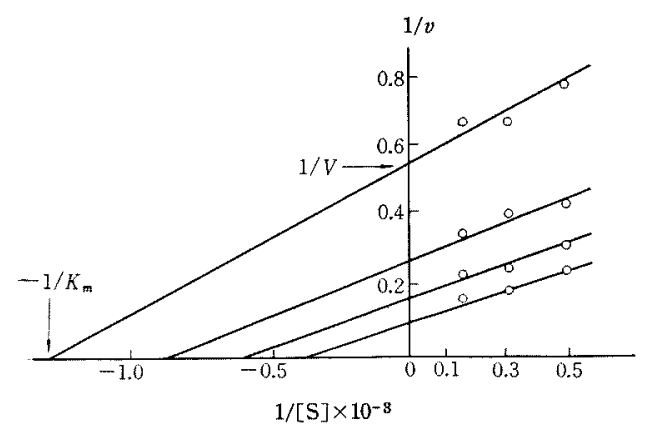

FIG. 8. Lineweaver-Burk Plot.

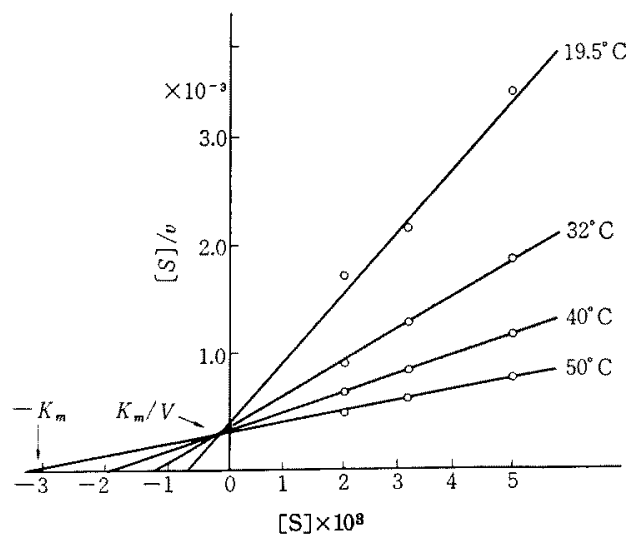

FIG. 9. Hofstee plot.

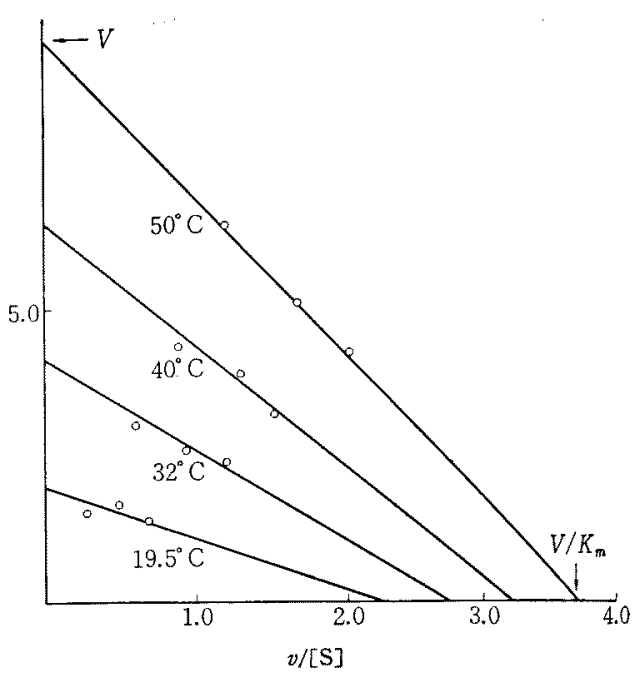

FIG. 10. Augustinsson Plot.

Table III. The Velocity ( $V$ ) AND MichaeIs Constant $\left(K_{m}\right)$ OBTAINED BY Plottring Methods (pH 8.3, substratate: BAA)

Temp.

Plot Method $\quad 19.5^{\circ} \mathrm{C} \quad 32^{\circ} \mathrm{C} \quad 40^{\circ} \mathrm{C} \quad 50^{\circ} \mathrm{C}$

Lineweaver- $\left\{\begin{array}{llllll}V & 1.76 & 3.65 & 5.88 & 10.0\end{array}\right.$

BurkPlot $\left\{\begin{array}{lllll}K_{m} .10^{3} & 0.81 & 1.25 & 1.72 & 2.94\end{array}\right.$

Horstee plot $\left\{\begin{array}{lllll}V & 2.84 & 4.43 & 5.81 & 6.57 \\ K_{m} .10^{3} & 0.80 & 1.33 & 1.86 & 2.89\end{array}\right.$

Augustinsson $\left(\begin{array}{llllll}V & 1.70 & 3.90 & 6.20 & 9.50\end{array}\right.$

plot $\quad\left\{\begin{array}{lllll}K_{m} .10^{3} & 0.895 & 1.42 & 1.88 & 2.64\end{array}\right.$

Average $\quad\left\{\begin{array}{lllll}V & 2.10 & 3.99 & 5.96 & 8.69 \\ K_{m} .10^{3} & 0.83 & 1.33 & 1.82 & 2.82\end{array}\right.$

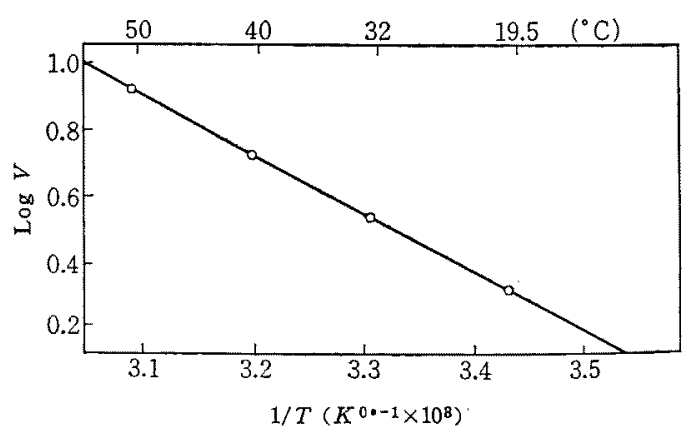

FIG. 11. Arrhenius Plot of the Purified Protease.

The rate of reaction was measured at $\mathrm{pH} 8.3$ using $\mathrm{BAA}$ as substrate. 
Table IV. Kinetic Data of Proteolytic Enzymes from Different Sources

$\begin{array}{llcrrrr}\text { Enzymes } & \text { Substrates } & \mathrm{pH} & \text { Temp. }{ }^{\circ} \mathrm{C} & \begin{array}{c}K_{m} .10^{3} \\ \mathrm{~mol} / \mathrm{l}\end{array} & \text { Ea } & \begin{array}{c}\text { References } \\ \text { Trypsin }\end{array} \\ \text { Cohymotrypsinogen } & 7.5 & 37 & 1.2 & & (16) \\ \text { Cockroach protease } & \text { azoalbumin } & 7.8 & 6 \sim 37 & & 14,900 & (1) \\ \text { House-fly protease } & \text { azoalbumin } & 7.8 & 10 \sim 50 & & 16,000 & (1) \\ \text { Streptomyces griseus pronase } & \text { Gly-L-Leu } & 8.3 & 40 & 12.5 & 2,700 & (17) \\ \text { Cricket protease } & \text { BAA } & 8.3 & 50 & 2.8 & 3,770 & \end{array}$

son plot ${ }^{12)}$ were used. These are shown in Figs. 8,9 and 10, respectively.

Data from three plots with their respective averages are shown in Table III.

(C) Determination of the activation energy ( $\mathrm{Ea})$ of the CM-cellulose-purified enzyme. The activation energy of the CM-cellulose-purified enzyme was obtained by the performance of an Arrhenius plot. The plot was performed at $\mathrm{pH} 8.3$ and is shown in Fig. 11.

The activation energy (Ea) was calculated to be $3,770 \mathrm{cal} / \mathrm{mol}$.

For comparative purposes, results of kinetic studies of proteolytic enzymes from various sources are shown in Table IV

Cricket protease had an Ea similar to that of pronase of Streptomyces griseus, however, there was a marked difference in $\mathrm{Ea}$ from the proteolytic enzyme of housefly, cockroach and trypsin. The latter three had an Ea approximately 4 times greater than that of cricket protease. The $K_{m}$ of cricket protease was close to that of trypsin but was 4 times less than that of pronase.

\section{DISCUSSION}

In the purification of crude cricket protease, $0.2 \%$ rivanol (Step 4 in Table I) was employed to remove contaminating amylase. Assay of the rivanol-treated protease showed that approximately $70 \%$ of the contaminating amylase had been removed.

Since the enzyme was not adsorbed to DEAE-cellulose (OH-form) but was adsorbed to CM-cellulose, it probably indicates the basic nature of this protease. When CM-

12) K.B. Augustinsson, Arch. Biochem., 23, 111 (1949). cellulose in the $\mathrm{H}$-form was used, the eluted enzyme had no activity, however, CM-cellulose in the $\mathrm{Ca}$-form did not inactivate the enzyme. Therefore, Ca-form was used following the work of Nomoto ${ }^{13)}$ who used Ca-form cation exchange resins in the purification of pronase. By use of CM-cellulose in the Ca-form there was 18 -fold increase from the initial water extraction of cricket protease.

These facts infer that the cricket protease is a type of metalloenzyme.

Studies of the effect of $\mathrm{pH}$ on enzyme activity indicated that cricket protease was similar to trypsin in that optimum activity was under alkaline condition $(\mathrm{pH} \quad 8.0)$, whereas activity was insignificant in the acid medium. It was noticed, however, that the optimum temperature $\left(50^{\circ} \mathrm{C}\right)$ of cricket protease was higher than that of trypsin. With respect to $\mathrm{pH}$ stability, the activity of cricket protease was preserved like trypsin under acid condition ( $\mathrm{pH} 3.0$ ).

The dialysis of cricket protease at $5^{\circ} \mathrm{C}$ with water containing no metals completely inactivates the enzyme. When suitable metals are then added to the inactivated enzyme, activity does not return. However, when the dialysis is carried out in the presence of certain metals, cricket protease is stabilized most efficiently by $\mathrm{Al} .^{+++}$Divalent ions such as $\mathrm{Ca},{ }^{++} \mathrm{Mn}^{++}$and $\mathrm{Co},{ }^{++}$which are effective to the stabilization of trypsin, $\alpha$-chymotrypsin ${ }^{14}$. and pronase from Streplomyces griseus, ${ }^{131}$ are

13) M. Nomoto and K. Narahashi, Riken Hokoku, 35, 90 (1958).

14) P. Desnuelle, in "The Enzyme" ed. by P.D. Boyer, H. Lardy and K. Myrbäck, Vol. 4, Acad. Press, New York: and London, 1960, p. 93, 119. 
rater poorly effective. In addition, it is known that divalent ions such as mentioned above increase the enzymatic activity of trypsin and $\alpha$-chymotrypsin. ${ }^{15,16)}$ In the case of cricket protease, however, it has to be concluded that a certain metal is rather essential for it's activity in the same meaning as pronase requires $\mathrm{Ca}{ }^{++13)}$

It is generally known that the specificity of protease in mammals is remarkably high, but that in bacteria or molds is relatively low. Since cricket protease and mammalian trypsin are both specific for $\alpha$-benzoyl-L-arginine amide it appears that the cricket shows similarity to the mammals with respect to enzyme property. The calcium form of cricket pro-

15) N.H. Green, J.A. Gladner, Cunninham, Jr., and H. Neurath, J. Amer. Chem. Soc., 74, 2122 (1952).

16) N. M. Green and H. Neurath, J. Biol. Chem., 204, 379 (1953) tease was employed in substrate-specificity studies and also in the kinetic studies to follow involving $\alpha$-benzoyl-L-arginine as substrate. Under the conditions of the assay the aluminum form of cricket protease was not stable and precipitated.

From kinetic observations, cricket protease appears to be unique in that it has similar Michelis constant $\left(K_{m}\right)$ with mammalian but differed considerably in the value of activation energy (Ea) from mammalian and other insects such as the cockroach and housefly. Also, it had a similar Ea with pronase from Streptomyces griseus but there was considerable difference in $K_{m}$.

Acknowledgements. The authors wish to thank Prof. Y. Oshima for his support of this project. 